Бојан Јовановић

jovanovic.b@gmail.com

https://doi.org/10.18485/rit.2021.19.35.2
УДК: $316.613 .4: 316.7$

$27-423.7$

179.9

Оригинални научни рад

Датум пријема: 7.10.2020.

\title{
АНТРОПОЛОГИЈА ПОНОСА И СТИДА
}

\begin{abstract}
Резиме

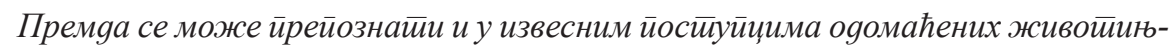

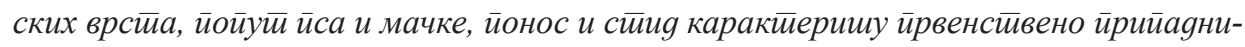
ке љуяских зајеgница. Засновани на ирримарном дихойомном обрасиу ӣозийивной и неїайивног одређења, иожељни и нейожељни йосииуици су изражавани као йонос

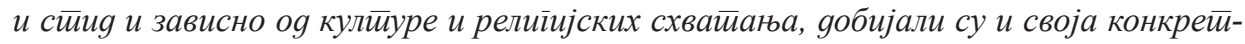
на обележја. Размайрајући значај хришћанскоі йоимања йоноса и сйияа у разво-

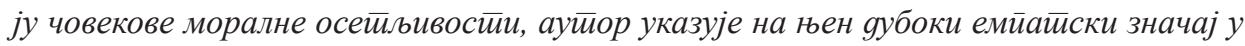
йојави изазивања йаквих осећања не само збоі својих, већ и збоі йосйуйака gруіих.
\end{abstract}

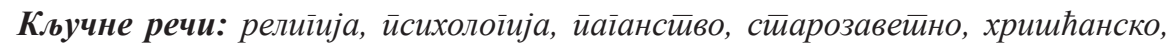
осећање, морал

Када се у контексту религије, филозофије и уметности настоји да сагледа значај поноса и стида, онда приступ овим осећањима подразумева, најпре, њихово психолошко одређење изражено на свој начин и у појединим областима културе. Посебно је значајно искуство које је о овим осећањима исказано у религији као духовном оријентиру традиционалне култуpe. У том смислу антрополошки приступ, заснован на сазнањима из области веровања и религијске праксе, постаје важан и за разумевање ових осећања и у данашњем свету. Битно је, дакле, адекватно сагледавање фактора који условљавају да се људи стиде или поносе због онога што чине или што су учинили.

Схваћени као дијаметрално супротна осећања, стид и понос се карактеришу опозитним значењским одређењима у социјалном контексту. У том амбијенту се ствара и потврђује значење пожељних и непожељних поступака, доброг и лошег понашања. Сматрајући да је због свог понашања, казивања или изгледа у очима других опажен као недостојан или мање вредан, појединац се осећа постиђеним. С обзиром да се стид несвесно испољава у 
његовом понашању, евидентно је да су корени таквог осећања пред другим знатно дубљи. Показивање стида се не учи експлицитно, већ је он несвесна манифестација непријатности, а почиње да се испољава у понашању детета пре него оно наврши две године ${ }^{1}$. Од доласка на свет оно се учи култури и придржавања њених правила, а свест о њиховом кршењу исказује се осећањем стида и кривице ${ }^{2}$. Тај неугодни осећај човек манифествује карактеристичним гестовима, обарањем погледа, спуштањем главе, прекривањем лица рукама, скрушеним изгледом, повлачењем у себе и општом тежњом да умањи своју величину. Осећајући да је унижен и да је доведен у питање његов идентитет, он би у том тренутку највише желео да га нема, па зато и каже да би тада најрадије "пропао у земљу". Будући да спада у осећање самопроцене, стид има важну улогу у развоју свести о себи, одакле проистиче и мотив за одбрану ега од природних нагонских импулса који би могли да доведу у питање његов интегритет.

Стид има и латентну позитивну индивидуално психолошку функциjy, jер чува човекову интимност и приватност од нежељених приступа других. Тај сегмент његовог живота, изван социјалног амбијента у којем постоји доступно знање о свим члановима колектива, има за њега, и њему блиским особама, значење тајне. Зато уклањањем стида као чувара интиме, садржај личног живота појединца постаје опште доступан, јер се он отвара и показује спремност да зарад популарности у ријалити програмима медијски објави своје највеће животне тајне. Када у датој средини постоје јасни критеријуми о томе шта је пристојно, а шта непристојно, онда свако непристој-

1 Посматрајући израз осећања кривице, односно стида код своје деце због откривања њиховог малог преступа у раном добу, Дарвин утврђује да је тај израз био веома јасан код детета старог две године и седам месеци. Упор. С. Darvin, Izražavanje emocija kod čoveka i životinja, Dosije studio, Beograd, 2009, 266. Према психоаналичком схватању, дете не познаје стид пре периода латенције, односно до своје пете или шесте године када почиње да развија ово осећање које постаје душевна брана од нагона. Упор. Ж. Требјешанин, Речник йсихолоïuje, Агапе књига, Београд, 2018, 556. - Међутим, према нашем сазнањима, дете већ у периоду након годину и по дана почиње да изражава карактеристичним гестовима неугодно осећање стида због опомињања на непоштовање правила којима се учи или због присуства непознате особе пред којом се од њега тражи да покаже научено.

2 Иако ће се потом успоставити разлика између ових осећања, на њихову бликост упућује и кривица и стид логораша који су преживели Холокауст. Изашавши из нацистичких логора у којима су страдали најближи чланови њихових породица, рођаци и пријатељи, они су постали оптерећени дуготрајним, интензивним и болним осећањем кривице и стида због нељудског третмана и доживљених понижења у тим логорима. Како објективно нису били криви због страдања својих ближњих, осећање кривице постајало је несвесно и уступало је место стиду. Будући да су у истим нељудским околностима страдали они које су преживели изузетно ценили, њихов стид је последица моралног осећања неправде захваљујући којој су их надживели. 
но, неприлично понашање има за последицу непријатан осећај стида. Међутим, тај осећај се губи променом социокултурног контекста у којем је он имао своје одговарајуће значење.

За разлику од стида, понос је супротно осећање, које појединац настоји да изрази подизањем главе, испрсавањем и тежњом да буде примећен и покаже своју величину и важност. Некада се осећање поноса, након учињеног подвига, изражавало и бусањем у груди.

\section{Срам и стид}

Стид је примарно повезан са страхом, јер страх настаје због блокираног бекства од опасности ${ }^{3}$, а његове карактеристике се манифествују и у стиду осећањем због спутаног бекства од особе пред којом је доживљена неугодност. У потоњем развоју, ове емоције су се диференцирале ${ }^{4}$. Стид се испољава неконтролисаним црвенилом лица ${ }^{5}$, а чињеница да се психопате не стиде, а идиоти ретко црвене ${ }^{6}$, показује одређене претпоставке за овакво морално осећање. Одсуство стида индикатор је, према Фројду, ниског нивоа интелигенције, из чега се и изводи да се само глуп човек не стиди. Не показујући стидом да му је угрожена личност и да му прети опасност од губљења достојанства, он тиме показује низак степен осећања заједнице ${ }^{7}$. Зато је илузија да се такве особе без могућности адекватног осећаја стида могу због својих недела постидети чињењем добрих дела. Осрамоћени је морално понижен и симболички се сматра да је укаљао свој образ који се, за разлику од руку, тешко пере. У односу на оног који га је прљањем оцрнио, за оног који превлада искушења и покаже своје јунаштво каже се да је обелио образ. У традиционалним друштвима изузетно се држало до моралних категорија, па одатле и Његошево упозорење: „Част и брука живе довијека“, јер се пазило на то како ће ко бити запамћен.

Развијен, дакле, из првобитног синкретичког облика у којем је био повезан са страхом, стид као осећање треба разликовати од стидљивости, као личне особине, попут скромности ${ }^{8}$, па је разумљиво да личности са наведеним менталним карактеристикама, немају осећај стидљивост као

3 K. Outli, Emocije: kratka istorija, Clio, Beograd, 2005, 45.

4 C.. Darvin, Ibid, 322.

5 Ibid, 307.

6 Ibid, 308.

7 A. Adler, Poznavanje čoveka, Prosveta, Beograd, 2007, 289.

8 P. Ekman, komentar u knjizi Č. Darvin, Izražavanje emocija kod čoveka i životinja, Dosije studio, Beograd, 2009, 316. 
особине, односно претпоставке за такво осећање. У том смислу и треба разликовати индивидуално психолошки стид од социокултурног срама, односно срамежљивости (стидљивости, постиђености) као првенствено социјалне категорије. Иако се ова осећања поистовећују, а њихова одређења сматрају синонимима, стид и срам се разликују зависно од њихове доминантне, јер у стиду преовладава психолошки, а у сраму његов социјални аспект. Стид може осетити појединац као последицу неког свог поступка или казивања због само њему познатог разлога везаног за његов лични живот и интимно искуство, док је срам социокултурно утврђена реакција осећањем непријатности због кршење важећих моралних, друштвених и културних правила, па се зато они који се не обазиру на своје непримерене поступке и опомињу да би због таквог свог понашања требало да се стиде. Диференцирањем стида од страха, и успостављањем разлике између стида и срама, настао је и страх од срама, односно срамоте и бруке, као социјалне непријатности која се доживљава и индивидуално психолошки као стид.

\section{Трагом божје промисли}

У свим религијама, од паганских до монотеистичких, па и у српској народној веровању, стид и понос су добијали своју артикулацију. О пореклу стида говори и старозаветна библијска прича о првим људима и њиховом понашању након кршења божје заповести. Када је створио човека и сместио га у Еден (Рај), Бог му је омогућио да слободно једе плодове са свих дрвећа, осим са дрвета знања добра и зла, јер му је запрећено да ће укусили ли од плода тог дрвета одмах умрети (Прва књ. Мојсијева, Постање, 2, 16-17.). Потом је Бог од Адамовог ребра створио и Еву, која је усвојила и придржавала се те забране.

Живећи наги у Рају, прве људе и није било стид (Постање, 2, 25). Међутим, када је на наговор змије, Ева појела забрањен плод, па га онда дала и Адаму да га и он окуси (Постање, 3, 1-6), онда се њима отворише очи и спознавши да су голи, сачинише себи прегаче од смоквиног лишћа (Постање, 3,7$)$, а чувши глас Бога који је шетао вртом, сакрили су се од њега међу дрвећем (Постање, 3,8 ). На Божје тражење да се не скривају, Адам одговори да се уплашио од њега, због своје голотиње. Бог увиђа да је то сазнање последица једења плода са забрањеног дрвета и зато протеривањем из Раја кажьава и змију и Еву и Адама $(3,23)$. Обучени у кожне хаљетке, изгна- 
ни људи су постали блиски Богу по знању, па им је зато и ускраћена могућност да подлегну још већем искушењу да окусе од дрвета живота и остваре вечни живот $(3,22)$.

У природи нема стида јер он настаје са културом и почиње са човеком, који спознавши своју природну нагост, осећа нелагодност и потребу да прикрије своју голотињу. Тек, дакле, са успостављањем културних правила ствара се амбијент у којем њихово кршење има за последицу осећај неугодности изражен стидом. Човекова хуманизација природе огледа се у његовом утицају и на животиње које су припитомљавањем постале део његовог света. О важности социјалног амбијента за профилисање овог осећања говори и понашање кућних љубимаца, паса и мачака. Наиме, када учине неки прекршај због којег се кажњавају или вербално укоре, они се повлаче у себе, и постиђени одлазе изван уобичајено социјалног простора да тамо негде у ћошку сачекају док не истекне време казне и осећај непријатности када се самоиницијативно или на позив укућана враћају. Идентична њиховом односу према људима, била је и описана реакција првих људи према Богу, од којег се они плаше и од којег су се стидели.

У опису реаговања људи на сопствену нагост истиче се постојање свести, односно знања стеченог кушањем забрањеног плода. Иако су импровизованим прегачама од лишћа прикрили своју нагост, они се више не стиде да се појаве пред Богом у том природном, непристојном стању, већ осећају нелагодност због учињеног прекршаја. Инстанца пред којом појединац осећа стид је она која је више од њега и од које он зависи и страхује. Стид је осећање које настаје због свести о учињеном и помишљеном прекршају. Зато веровање у постојање надзора, контроле и кажњавања, смањује човекову природну тежњу да крши постојећа правила и законе да се због тога не би осећао неугодно и да се не би стидео. Истоветно веровање га храбри да чини дела која колектив позитивно вреднује да би био поносан на себе.

Увек када природа порази културу, када нагонско у човеку преовлада и поништи духовност он осети стид због своје огољености, свођења на ниже од његових могућности. То је, дакле, исконско осећање које се јавља према обрасцу у освиту човековог постојања, са кршењем божје наредбе, које је део божјег плана ${ }^{9}$. Већ сама забрана, претпоставља њено нарушавање, па је наглашавање њеног поштовања само подстицај оспоравању. Зато када Бог манифестно истиче ту забрану, он латентно опомиње на могућност њеног кршења. У Божјој промисли није то тако непредви-

9 Upor. B. Jovanović, Bliskost dalekog, Stylos, Novi Sad, 2005, 131. 
ђено и неочекивано као што се представља, јер авантура постајања човека подразумева повишену свест и излазак из природе. И сам осећај стида је плод човеког психолошког сазревања. Треба бити свестан и имати осећај за стид, што се тумачи и као знање, јер онај који не зна за стид, нема препреке да се јавно оголи и прикаже своју нагост и бестијалност, дичећи се њоме.

\section{Старозаветно искушење}

Када се човек распојаса, оголи, врати природи, регредира на нижи степен своје културе, заигра око златног телета, као када је Мојсије видео свој голи народ, како се понаша у његовом одсуству, како је поводљиво послушао Арона на сопствену срамоту пред противницима својим, и показао се у лошем светлу, онда такво бесрамно понашање провоцира агресивну реакцију. Бацивши плоче на којима су биле исписане божје заповести као нови закон, Мојсије уништава златно теле и окупивши око себе истовернике наређује да се побију сви који му нису приступили (Друга књига Мојсијева 32, 19-30). Тако мачем успоставља веру у једног бога, Јахвеа, и утемељујући монотеизам међу Јеврејима добија међу својим сународницима статус највећег законодавца и пророка.

Са законом је успостављена и култура која је била поуздана одбрана од искушења паганског, огољавања до природног, и стида. У односу на дотадашње паганство, које је остало стално човеково искушење, старозаветна религиозност представљала виши степен развоја религијске свести чије је институционализовање, оличено у тадашњим свештеницима и фарисејима показало и етичка ограничења која ће бити превазиђена новозаветним учењем Исуса Христа. Та ограничења Исус јасно показује демаскирајући њихове ставове према починиоцима зла и успостављања новог етичког принципа саможртвености и правде. Парабола о стиду из Новог завета, указује како се губи и обнавља то осећање.

\section{Хришћанска обнова моралности}

Домаћин који је засадио виноград, оградио га плотом, саградио стражарску кулу и пивницу, дао га је у закуп виноградарима. Када је дошло време бербе, послао је своје слуге да узме свој део рода, али виноградари једног слугу истукоше, другог убише а трећег најурише. Када су и слуге које 
је опет послао доживеле исту судбину као и њихови претходници, власник је послао свог сина сматрајући да ће се од њега постидети (Мт 21, 37) и испоштовати договор. Међутим, виноградари поступише са њим исто као и са домаћиновим слугама, и из жеље да присвоје виноград убише га (Мт 21, 39).

На Исусово питање првосвештеницима шта ће господар учинити виноградарима када лично дође на свој посед, они одговорише да злочинце треба погубити, а виноград дати другим закупцима који ће му давати пристигле плодове (Мт 21, 41). Тада им Исус рече да, према Писму, одбачени камен, постаје главни угаони темељник, чиме је алегоријски опоменуо првосвештенике и фарисеје да ће се од њих узети Царство Божје, и да ће се дати народу који доноси плодове. Када им указа на то да ће се разбити онај ко падне на тај камен, а да ће бити сатрт онај на кога он падне, они се уплашише, јер схватише да се то на њих односи, и настојећи да ухвате Исуса нису то чинили због страха од самог народа који је Исуса сматрао пророком (Мт 21, 45-46).

У овој причи о стиду и страху, бестидни виноградари су у жељи да присвоје виноград убили не само власникове слуге, већ и његовог сина који је дошао да их опомене. Власник је рачунао да ће од његовог сина, уколико нису од његових слугу, имати обзира и стида и држати се и поштовати договор. Испоставило се, да заслепљени егоизмом постају безобзирни и бестидни, али и немоћни у својој охолости, јер моћни постају одбачени и да народ који је прихватио Исуса постаје носилац моралних и духовних вредности битних за људски опстанак. Народ је нашао у Исусу религијско утемељење и смисао свог самопотврђивања, а они који су изгубили осећај стида, фарисеји и првосвештеници, губе и дотадашњи значај. Народ је постао огледало пред којим се обнавља осећај стида. Зато је тај преображај и праћен неком врстом поноса, којим је означено не само ступање на сцену нове вере, већ и значај самоодрицање и саможртвености као основе духовног и моралног подвига који је сваки појединац морао да чини, а мора и данас, у тежњи да се потврди као хришћанин.

На основу изнетих примера видимо да је човек започео да се стиди у стању идентичном сну, у рајском врту, када није имао довољно свести о значењу учињеног. Тада и почиње његово разликовање добра од зла, свест о кршењу забране и осећај греха, који током историје постаје његово обележје. Од тада, он има могућност да се свесно определи за кршење правила, закона и моралних начела, због чега се осећа нелагодно, стидно. А тај осећај се 
јавља не само када он лично чини прекршај, већ и када то раде други. Што доказује да је осећај стида дубоко у њему и да има своју архетипску основу.

\section{Бестидно време}

Повезан са осећајем кривице због кршења постојећих друштвених и моралних правила, стид се не јавља код психопатаских особа које немају тај осећај за сопствену одговорност и емпатију. Они су у стању да причају и евоцирају ситуацију кршења тих правила, да истичу себе и уживају у делима због којих би се други стидели. Но, то је, дакле, посебна групација људи која се и не каје због учињеног, и нема мотива да тражи извињење или опроштај, а још мање да испашта за извршен злочин.

Уколико појединац то и не осећа, он се опомиње да би требало да се стиди. Међутим, уколико се ти критеријуми снизе и нестану, онда он престаје да држи до свог образа. Показатељ безобзирног, бестидног времена у којем се губи осећај нелагодности због кршења постојећих моралних и друштвених огледа се у човекој спремности да себе оголи.

О појави нестајања стида међу људима говори и српско народно веровање везано за биљку стидак или срамак чији је бели цвет у средини мало црвен. Верује се да је управо тај црвени део био некада знатно већи али се стално смањује због губљења стида међу људима ${ }^{10}$. Забележено још у 19. веку, ово веровање је актуелно јер поставља питање о наговештају бестидног доба које је данас постало наша реалност ${ }^{11}$. О томе су говорили и песници, језиком који има и своју профетску димензију. У познатој песми „Наши дани“, Владислав Петковић Дис указује на тешку друштвену ситуацију у Србији пред Велики рат, која умногоме наликује и нашој данашњој стварности, и показује универзалне карактеристике моралног распада. Карактеристични стихови из те песме гласе: “Прогледале све јазбине и канали, / На високо подигли се сутерени,/ Сви подмукли, сви проклети и сви мали / Постали су данас наши суверени./ Прогледале све јазбине и канали. // Покрадени сви храмови и ћивоти, / Исмејане све врлине и поштење, / Понижени сви гробови и животи, / Упрљано и опело и крштење. / Покрадени сви храмови и ћивоти."

10 В. Чајкановић, Речник срйских нарояних веровања о биљкама, Сабрана дела из српске религије и митологије, књига четврта, Српска књижевна задруга, Београдски издавачко-графички завод, Просвета, Партенон М. А. М, Београд, 1994, 192.

11 B. Jovanović, Klopka za dušu, Stylos, Novi Sad, 2002, 13. 
Уколико се симболика храмова и ћивота разуме у значењу неупитних, светиг садржаја као темељних друштвених и моралних вредности, онда њихово пљачкање, поништавање и исмејавање постаје одлика доба у којем и долази до инверзије вредности и губљења осећаја одговорности. У таквом свету преовлађује површност и постаје све израженија равнодушност према осећању стида које добија значење некадашње људске вредности.

Данас људи као да губе осећање стида, па се живот у бестидном свету не исказује само повећањем броја оних који због структуре своје личности не могу да се стиде, психопате и идиоти, већ и као последица атеизациje, удаљавање од религије, преокретање традиционалних и хуманистичких вредности. Таква морална, друштвена и културна криза показатељ је аномичног социјалног стања које подстиче варварство. Када популарне личности у масмедијском свету постају појединци који се не стиде својих поступака, онда њихова ефектност постаје повод да се њиме поносе. Док су се некад и чланови њихових породица стидели њиховог понашања, данас се криминалци, лопови и проститутке поносе својим поступцима у друштву поштених и часних особа.

У време бешчашћа, превара и крађе, неугодно је и стидно бити частан и поштен. Појединац се може осећати нелагодно и у околностима када се одређена традиционална вредност сматра анахроном, превазиђеном, па је због тога у датом идеолошком контексту добила негативно значење. На пример, у време комунистичког једнопартијског атеистичког једноумља, религиозни људи су скривали то своје осећање, а уколико би се сазнало да присуствују литургији или славе крсну славу, били су исмејавани, као верски затуцани. Због тога су се осећали нелагодно, постиђено када би се открило да се тако понашају, па су својим кајањем обећавали да се више неће тако понашати.

У доба када је истополна склоност сматрана девијацијом и психичком болешћу, која имала и своју психијатријску шифру, геј особе су скривале и стиделе се те своје склоности. Данас се припадници ЛБГТ популације поносе својим сексуалним идентитетом, различитим од хетересексуалног обрасца, и тај свој понос демонстрирају парадирањем. Јавно показивање своје интиме и своје голотиње као начин самопотврђивања, показатељ је данашњег бестидног времена, које се тумачи као својеврсно предапокалиптично доба.

Моралан и честит човек који не чини добро другима због себе, већ због оних којима је помоћ потребна, осећа се нелагодно и стидно када га похвале 
због доброг дела које је учинио. Искрени патриотизам појединаца такође је изазивао осећај стида у околностима када се борба за отаџбину није посебно ценила. Људи који су доживели велико понижење, попут преживелих у Холокаусту, осећају стид и нерадо говоре о свом негативном искуству.

Осуду због кршења закона, друштвених и моралних правила, члан колектива доживљава и у осећају стида. Зато је стид, заштита од лагања, преваре, крађе. Лажљивци, преваранти, лопови који понављају своја недела, губе осећај стида као бране од неморала и кршења закона и правила културе. Тумачећи монструозне злочине над Србима у време НДХ, Јован Дучић је запазио да их Хрвати нису починили због своје храбрости, већ зато што се ничега не стиде. Та бестидност траје до данас у негирању геноцида, умањењу броја жртава и проглашавању Јасеновца, тог, како је утврдио Гидео Грајф, балканског Аушвица, радним логором.

Губљење стида код једних, не значи и губитак стида код свих људи и у бестидном добу. Истањена основа морала показатељ је њене вредности које остају свесни појединци као њени чувари. Попут оних 36 светских праведника који, према јеврејској легенди, одржавају свет од пропасти, и они доприносе очувању људског света пред опасношћу од његовог урушавања у бестидност. Због огољавања и непристојности других у нашим ријалити програмима, они су ти који се застиде пред таквим призорима. Међутим, као што се може стидети због других, тако се може и поносити због других, попут спортиста, чији се успех колективно прославља и доживљава као свој.

Сходно својој моралности, доследности у потврђивању етичких начела и осећању стида не само због својих, већ и туђих поступака, човек може бити поносан на то што чини. Из осећања стида, уместо других који су изгубили тај осећај, и долази понос са којим лакше у саможртвености носи своје бреме патње. Тај осећај не треба пренаглашавати, парадирати њиме и представљати себе жртвом ради стицања неке добити. Бити поносан, не значи истицати себе и сматрати себе већим од других због учињеног, јер се тада понос претвара у гордост и постаје грех. Превладати то искушење значи потврдити себе као биће које не само да помера границе својих моћи, већ и унутар тих граница, због поступака и понашања других може да реагује поносом или стидом. 


\section{Литература}

A. Adler, Poznavanje čoveka, Prosveta, Beograd, 2007.

Č. Darvin, Izražavanje emocija kod čoveka $i$ životinja, Dosije studio, Beograd, 2009.

P. Ekman, komentari u knjizi Č. Darvin, Izražavanje emocija kod čoveka i životinja, Dosije studio, Beograd, 2009.

B. Jovanović, Klopka za dušu, Stylos, Novi Sad, 2002.

B. Jovanović, Bliskost dalekog, Stylos, Novi Sad, 2005.

Нови завјеши, Свети архијерејски синод Српске православне цркве, Београд, 1984.

K. Outli, Emocije: kratka istorija, Clio, Beograd, 2005.

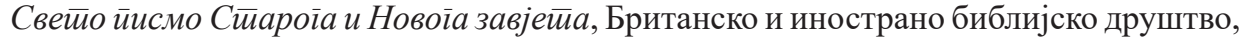
Београд, 1992.

Ж. Требјешанин, Речник йсихолойије, Агапе књига, Београд, 2018.

В. Чајкановић, Речник срйских нарояних веровања о биљкама, Сабрана дела из српске религије и митологије, књига четврта, Српска књижевна задруга, Београдски издавачко-графички завод, Просвета, Партенон М. А. М, Београд, 1994.

\section{Bojan Jovanović}

jovanovic.b@gmail.com

\section{ANTHROPOLOGY OF PRIDE AND SHAME}

\section{Summary}

Although it can be recognized in certain actions of domesticated animal species, such as dogs and cats, pride and shame characterize primarily members of human communities. Based on the primary dichotomous pattern of positive and negative determination, desirable and undesirable actions were expressed as pride and shame and, depending on culture and religious beliefs, they also acquired their specific characteristics. Considering the importance of the Christian understanding of pride and shame in the development of human moral sensitivity, the author points out its deep empathic significance in the phenomenon of provoking such feelings not only because of one's own, but also because of the actions of others.

Key words: religion, psychology, paganism, Old Testament, Christian, feeling, morality 